\title{
The Performance Study of Modified Glass Wool Board External Thermal Insulation System and the Application in the Energy-efficient Construction in Existing Building
}

\author{
Guo- Zhong LU ${ }^{1}$, Xue-Song ZHENG ${ }^{1}$, Xiu-Juan DING ${ }^{2, a,{ }^{*}, \text { Wei-Xuan ZHAO }}{ }^{2}$ \\ ${ }^{1}$ Engineering Technology Research Center of passive low energy building, Beijing, China \\ ${ }^{2}$ Beijing Building Materials Academy of Sciences Research, State Key Laboratory of Solid Waste \\ Reuse for Building Materials, Beijing, China \\ adingxiujuanlove@126.com \\ ${ }^{*}$ Corresponding author
}

Keywords: Modified Glass Wool Board, External Thermal Insulation System, Building Energy Efficiency.

\begin{abstract}
The composition, system construction, construction technology and function of glass wool board external thermal insulation system were introduced in this paper, the glass wool board was sewed warp and weft direction by basalt fiber and treated by waterproof and flame retardant interface agent (modified glass wool board), and the properties of the modified glass wool board and the system were also tested and analyzed. Results show that all the performance of the system meet the requirement of Technical specification for external thermal insulation JGJ144-2014 and Technical Specification for External Thermal Insulation Composite Systems Based on Glass Wool Board DB11/T1117-2014 company standard. A good effect was obtained by applying modified system in the energy-efficient construction in existing building of Xicheng district. Results demonstrate that the modified system is not only a new building fire insulation technology but also meets the building energy efficiency and fire resistance property requirements. Its market has a good prospect and promoting significance.
\end{abstract}

\section{Introduction}

Presently the thermal insulation system of the building external walls in China mainly adopts the polyphenyl plate thin plastering system. The primary thermal insulation material for the polyphenyl plate thin plastering system is organic combustible polystyrene foam, such as EPS and XPS, which are inflammable and shows little fire resistance. When flaming, these materials give out great smoke and high toxicity, and will be melted to drip when the temperature is up to $80^{\circ} \mathrm{C}$. Once the buildings applied EPS or XPS as external thermal insulation for external walls have caught fire, it will be very hard to put out the fire. In addition to the inflammability of polystyrene foam, the chimney effect and open effect born of the material's fast contraction and molten drop also prove to be the key reasons for the quick spreading of fire ${ }^{[1-3]}$. So we can see the fire resistance of this system is a little on the low side, and thus fail to achieve the effect of both energy saving and fire resistance. Although such materials help realize energy saving for the Chinese buildings, most of which are resided by concentrated population and designed in multiple stories and high-rise structures, great hidden fires have also been brought about, such as the auxiliary building at the new location of CCTV caught fire on Feb.9, 2009, and the great fire of a residential building in Shanghai on Nov.15, 2010, and other major accidents. All of these accidents lead to huge socio economic losses, heavy casualties and environmental pollutions ${ }^{[4,5]}$. Considering this, it is of great urgency for a product to be available in 
the current building material market which will enable the technical insulation design for buildings, eliminate hidden fire and will not make it difficult for the construction or increase the project cost.

In terms of the hidden fire of the external thermal insulation system (ETIS), the following two aspects are primarily considered.

a. Ignitability: In case of combustion source or kindling material, if the system can be ignited or give rise to combustion and the requirements on the system's intrinsic combustion performance.

b. Transmissibility: In case of combustion or fire, if the system can spread flame as well as the requirements on the system's resistance to external fire or on the fire resistance performance.

Modified glass wool board is a type of highly efficient inorganic thermal insulation material. Compared with organic polystyrene, polyurethane and other foam insulation materials, this material is characterized by incombustibility (grade A), free of flame ignitability or transmissibility and shows low unit weight, low heat conductivity coefficient, fire resistance, nontoxicity, stable chemical property and long service life. Therefore, it proves to be an ideal thermal insulation material and can be widely used in various industries. The wind load performance, weather resistance, shock strength and other performance of the modified glass wool board for ETIS comply with all the indicators of THE JG144-2004 Technical Specification for External Thermal Insulation on Walls.

\section{Materials and Structures of the Modified Glass Wool Board-based ETIS}

\section{Materials}

Glass wool board is produced through the following processes. Melt cullet, silica sand, dolomite, sodium carbonate, borax and other materials into glass before making it into fibers. After spraying special thermosetting adhesive, press these fibers into board-shaped thermal insulation material, as shown in Fig.1. The application of glass wool board to external insulation system of external walls will exhibit desirable fire resistance, thermal insulation, energy saving and sound insulation performance, but there are also some problems. Firstly, the tensile strength in the vertical direction of the glass wool board and the board is a little on the low side, i.e. generally lower than $7 \mathrm{kPa}$. Secondly, the material shows low resistance to water and alkali. When exposed to alkaline environment, it is prone to corrosion which leads to a sharp decline in strength. Through research on the issue of low strength, we adopt the longitude and latitude sewing of glass wool board to raise its tensile strength perpendicular to the board, which will be increased to over $15 \mathrm{kPa}$, as shown in Fig.2. Targeted at the low resistance to water and alkali, the water and alkali resistance adhesion agent has been applied to covering the six facets of the glass wool board as a way of raising its water resistance. Meanwhile, the glass wool board and the alkaline environment will be isolated to raise its alkali resistance. All these efforts bring about the modified glass wool board, as shown in Fig.3.

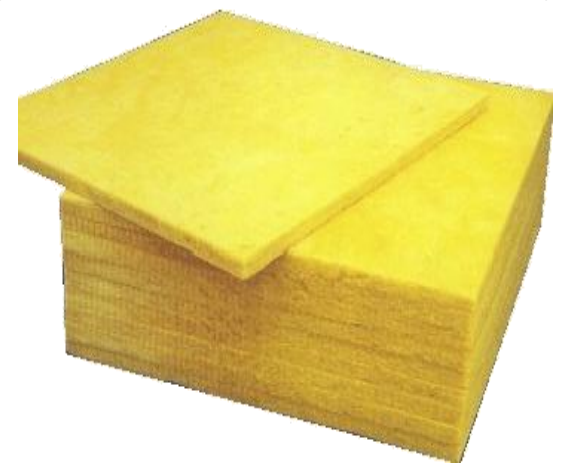

Fig.1 Bare Board 


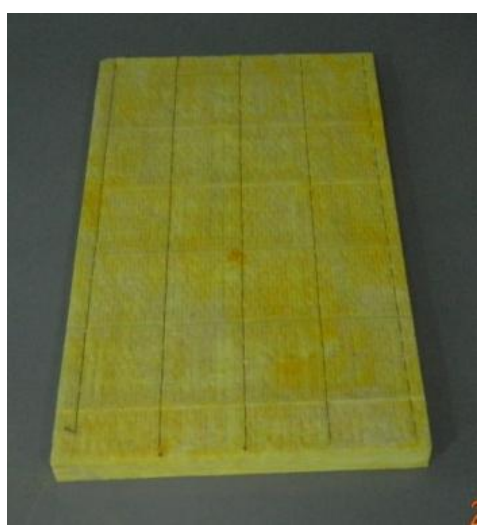

Fig.2 Sewn Board

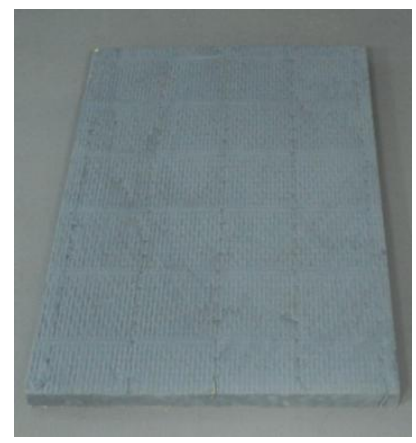

Fig.3 Modified Glass Wool Board

\section{System Structure}

The modified glass wool board for external insulation system of external walls as mentioned here in this paper is mainly made of glass wool board (thickness $\geq 50 \mathrm{~mm}$; unit weight $100 \mathrm{~kg} / \mathrm{m}^{3}$ ) as thermal insulation material and in combination with mortar specially for glass wool board, alkali-resistant glass fiber mesh and bracket, anchor bolt and other auxiliary materials to form a solid, integrated external insulation system for building external walls. Fig.4 is for its basic structure.

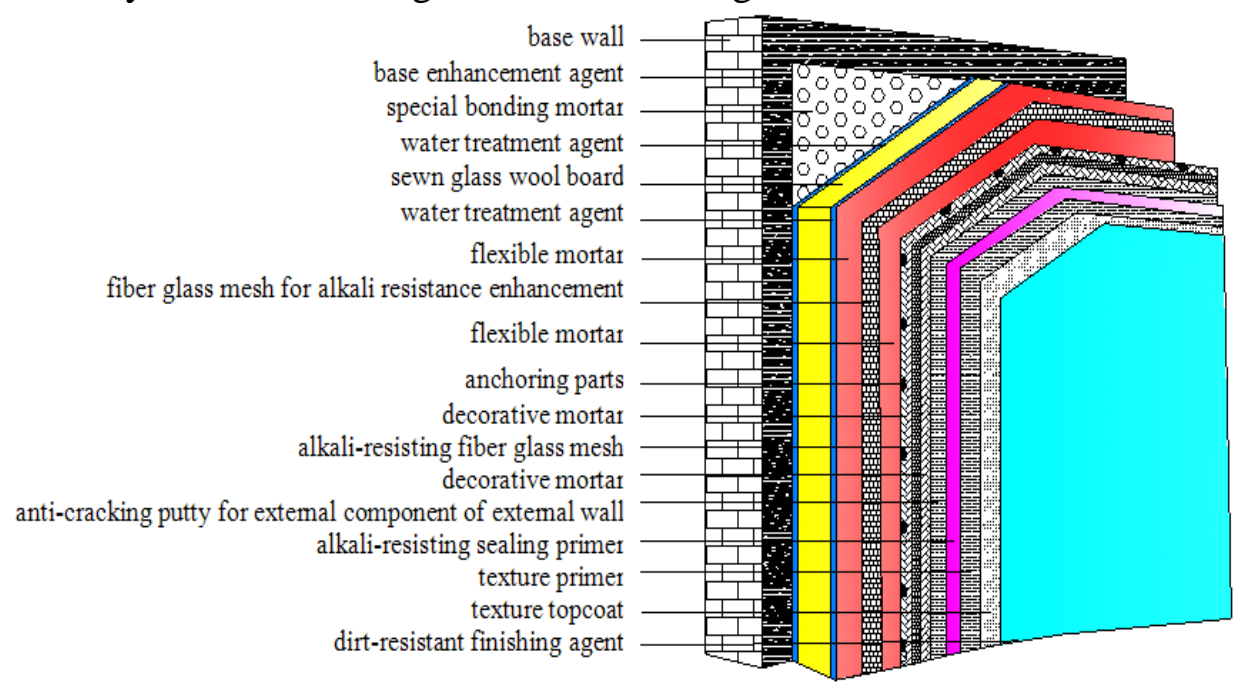

Fig.4 Structure on Modified Glass Wool Board-based ETIS

This system has the following performance and features.

1. Ensure the system's safe connection from the angle of system design 
The plant carries out pretreatment to improve the strength, waterproofness and alkali resistance of the glass wool board.

Improve the system's mechanical connection strength through double reinforced mesh, anchor bolt, and bracket.

Improve the construction operability through flexible mortar and insulation board interface treatment so as to reduce the occupational health hazards to employees.

The node design is fit for the system structure.

2. High-performance auxiliary materials ensure the system's long durability.

Proceeding from the structure of the thermal insulation system, special adhesion agent, polymer binding mortar, flexible mortar, polymer decorative mortar, and finishing material supportive to the glass wool board;

The special adhesion agent exhibits water resistance and reinforcing effect; the flexible mortar is capable of leveling and thermal insulation.

3. Favorable thermal insulation

The heat conductivity coefficient of glass wool board for external thermal insulation is around $0.033 \mathrm{~W} /(\mathrm{m} \bullet \mathrm{K})$, and the heat conductivity coefficient of flexible mortar is $0.060 \mathrm{~W} /(\mathrm{m} \cdot \mathrm{K})$. Integration of the two materials invests the entire system with wonderful thermal insulating property. Meanwhile, the flexible mortar can serve as supplement to the thermal insulation of the parts that cannot be treated by glass wool board and of the thermal bridge whilst blocking the thermal bridge.

4. Excellent fire resistance

The external thermal insulation system (ETIS) of glass wool board adopts grade-A insulation board which invests the entire system with excellent fire resistance and is highly effective in protecting the building structure.

5. Excellent shock resistance

The glass wool board is relatively elastic and can achieve desirable rebounding effect. Meanwhile, the system adopts the double alkaline-resistant fiberglass gridding cloth that forms a double mesh structure and thus invests the material with excellent shock resistance.

6. Strong adaptability to the deformation of main structure and favorable crack resistance

Glass wool board is a type of material that can withstand large flexible deformation and is highly effective in withstanding external deformation. In case of external force, temperature deformation, dry and wet-incurred deformation and other factors, the material shows small deformation and great rebounding capacity after deformation, which effectively ensures the stability and durability of the system. At the same time, the entire ETIS is a flexible crack resistance system that is capable of gradual change of flexibility and of releasing stress layer by layer, and thus exhibits desirable crack resistance.

\section{Research on the Performance of the Main Material of the Modified Glass Wool Board-based ETIS}

The core material for the modified glass wool board-based ETIS is modified glass wool board. But the key of the construction technology lies in the performance of its bonding mortar and decorative mortar. Generally, bonding mortar and decorative mortar prepared from polymer modified mortar and cement are used to meet the construction requirements.

\section{Experimental Study of Adhesive Mortar}

Currently two types of polymer modified mortar are available in the market, i.e. two-component adhesive mortar and one-component adhesive mortar. The two-component adhesive mortar is based on the liquid ingredients of polymer emulsion and its additives as well as the power component of 
cement, sand, and water retention agent. During application, the two groups of components shall be mixed as per specific ratio and can be put into used after evenly mixed. The one-component adhesive mortar is a type of dry mixture that is made up of powder polymer, cement and other materials through blending. During application, add water to the material in appropriate ratio and then mix them evenly. Based on the same technical characteristics, one-component adhesive mortar shows such advantages as simple production process, convenient storage and shipping, easy control of quality on the construction site and low comprehensive cost compared with the two-component adhesive mortar. For this reason, this experiment considers the experimental study of the one-component adhesive mortar only. The main materials and their specifications for the experiment are shown as follows.

Cement: P.O 42.5, ordinary Portland cement, silica sand 40-70 meshes, rubber powder 1: redispersible emulsion powder $5010 \mathrm{~N}$, rubber powder 2: redispersible emulsion powder 5044N, cellulose ether: HPMC (hydroxypropyl methyl cellulose). In order to find out the best proportioning, refer to Table 1 and Table 2 listed below for the experimental scheme and results.

Tab.1 Experimental Scheme of Bonding Mortar

\begin{tabular}{|c|c|c|c|c|c|c|c|c|c|c|}
\hline & $1 \#$ & $2 \#$ & $3 \#$ & $4 \#$ & $5 \#$ & $6 \#$ & $7 \#$ & $8 \#$ & $9 \#$ & $10 \#$ \\
\hline Cement $/ \%$ & 25 & 30 & 25 & 30 & 25 & 45 & 40 & 25 & 25 & 30 \\
\hline Silica sand /\% & 65 & 60 & 65 & 60 & 65 & 45 & 50 & 65 & 65 & 60 \\
\hline Mineral admixture /\% & 7.8 & 7.8 & 6.8 & 7 & 7 & 7.8 & 6.8 & 8 & 10 & 6.8 \\
\hline Rubber powder 1/\% & 2 & 2 & 2 & 2 & 3 & 2 & 2 & 2 & 0 & 2 \\
\hline Rubber powder $2 / \%$ & 0 & 0 & 1 & 1 & 0 & 0 & 1 & 0 & 0 & 1 \\
\hline Cellulose ether /\% & 0.2 & 0.2 & 0.2 & 0 & 0 & 0.2 & 0.2 & 0 & 0 & 0.2 \\
\hline
\end{tabular}

Tab.2 Experimental Results of Bonding Mortar

\begin{tabular}{|c|c|c|c|c|c|c|c|c|c|c|c|}
\hline & & $1 \#$ & $2 \#$ & $3 \#$ & $4 \#$ & $5 \#$ & $6 \#$ & $7 \#$ & $8 \#$ & $9 \#$ & $10 \#$ \\
\hline \multirow{2}{*}{$\begin{array}{l}\text { Tensile bond strength } \\
\text { (with cement base) } \\
\text { /MPa }\end{array}$} & $\begin{array}{l}\text { Original } \\
\text { strength }\end{array}$ & 0.87 & 0.83 & 0.88 & 0.82 & 0.81 & 0.75 & 0.76 & 0.80 & 0.65 & 0.81 \\
\hline & $\begin{array}{c}\text { Water } \\
\text { resistance }\end{array}$ & 0.79 & 0.78 & 0.84 & 0.75 & 0.77 & 0.68 & 0.70 & 0.78 & 0.57 & 0.79 \\
\hline \multirow{2}{*}{$\begin{array}{l}\text { Tensile bond strength } \\
\text { (with glass wool board) } \\
/ \mathrm{kPa}\end{array}$} & $\begin{array}{l}\text { Original } \\
\text { strength }\end{array}$ & 41 & 40 & 41 & 41 & 41 & 39 & 39 & 41 & 41 & 42 \\
\hline & $\begin{array}{c}\text { Water } \\
\text { resistance }\end{array}$ & 41 & 41 & 40 & 41 & 40 & 38 & 37 & 41 & 40 & 40 \\
\hline \multicolumn{2}{|l|}{ Operational time $/ \mathrm{h}$} & 3.4 & 3.2 & 2.7 & 2.9 & 3.0 & 3.3 & 3.1 & 3.0 & 3.0 & 2.9 \\
\hline
\end{tabular}

The following can be seen from Table 1 and Table 2 .

a. The addition of dispersible adhesive powder can improve the bonding strength, crack resistance and tenacity of bonding mortar, which will ultimately avoid the mortar's shrinkage crack and reduce the thickness of bonding layer.

b. The cement-sand ratio is also an important parameter that affects the brittleness coefficient. The results show that when the cement-sand ratio ranges from 1:1 to 1:2.5, the bonding strength of glass wool board exhibits no marked change, but the bonding strength of cement base shows a gradual increase. Generally, 1:2.5 proves to be the most appropriate ratio between cement and sand. 
c. By comparing $1 \#$ formula with $3 \#$ formula, it can be seen that the addition of rubber power 2 brings about marked coagulation and thus shortens the coagulation duration of the polymer cement mortar.

d. By comparing $1 \#$ formula with $8 \#$ formula, it can be seen that the addition of cellulose ether water-retaining agent brings about insignificant impact on the operable time and bonding strength of cement mortar.

In order to verify the experimental results, we have chosen $1 \#$ proportioning from the above experimental results for sample making before sending the sample to the Quality Control Department for testing. The testing results are shown in Table 3 listed below.

Tab.3 Testing Results on the Performance of Bonding Mortar

\begin{tabular}{|c|c|c|c|c|}
\hline \multicolumn{2}{|l|}{ Item } & Performance index & Test result & Conclusion \\
\hline \multirow{2}{*}{$\begin{array}{l}\text { Tensile bond strength (with } \\
\text { cement mortar) / MPa }\end{array}$} & Original strength & $\geq 0.60$ & 0.84 & Qualified \\
\hline & Water resistance & $\geq 0.40$ & 0.68 & Qualified \\
\hline \multirow{2}{*}{$\begin{array}{l}\text { Tensile bond strength (with } \\
\text { modified glass wool board) } \\
\qquad / \mathrm{kPa}\end{array}$} & Original strength & $\begin{array}{l}\geq 15 \text {, damage in the } \\
\text { modified glass wool board }\end{array}$ & $\begin{array}{l}44, \text { damage in the } \\
\text { modified glass wool } \\
\text { board }\end{array}$ & Qualified \\
\hline & Water resistance & $\begin{array}{l}\geq 15 \text {, damage in the } \\
\text { modified glass wool board }\end{array}$ & $\begin{array}{l}42, \text { damage in the } \\
\text { modified glass wool } \\
\text { board }\end{array}$ & Qualified \\
\hline \multicolumn{2}{|c|}{ Operational time $/ \mathrm{h}$} & $1.5-4.0$ & 1.5 & Qualified \\
\hline
\end{tabular}

It can be seen from the above analysis that the one-component adhesive mortar made of dispersible adhesive powder, cement mortar and its addition agents as well as the insulation board and cement mortar exhibit favorable original strength and water resistant adhesive strength. Upon testing, all its performance indicators comply with the requirements of the JG144-2004 Technical Specification for External Thermal Insulation on Walls.

\section{Experimental Study of Decorative Mortar}

The present decorative mortar is mainly made of cement-based materials and other polymer fillers and shall be applied to the outward of the insulation board in a thin layer, which plays a pivotal role in ensuring the system's mechanical strength and stability. For this reason, it is necessary for the decorative mortar to have the following performance.

First, the present decorative mortar belongs to the cement-based material which shows great brittleness and is prone to shrinkage distortion. In practical projects, when the decorative mortar is under direct solar radiation, heat will accumulate on the anti-crack mortar layer and its surface temperature can reach $50-70^{\circ} \mathrm{C}$. In the event of sudden rain, the surface temperature will quickly drop to around $15^{\circ} \mathrm{C}$. The heat conductivity coefficient of modified glass wool board is no higher than $0.035 \mathrm{~W} /(\mathrm{m} \bullet \mathrm{K})$ whereas the heat conductivity coefficient of anti-crack mortar is $0.93 \mathrm{~W} /(\mathrm{m} \bullet \mathrm{K})$, which shows a difference by 26 times. So the heat accumulated on the protective covering cannot diffuse through glass wool board. Big temperature change like this will inevitably lead to the sharp contraction of decorative mortar. Considering this, the decorative mortar must have a high flexibility.

Second, the external wall of buildings will inevitably undergo collisions. So this makes it necessary for the external mortar to be able to resist shock to some extent, and shall not have crack under normal shock or even damage the system.

Third, as the external wall will always be exposed to rains, the decorative mortar needs to have hydrophobicity and air permeability so as to keep water from entering and damaging the thermal insulation system and to evaporate the internal steam. 
Fourth, the decorative mortar shall have ideal bonding strength with the glass wool board and desirable construction performance.

Considering the above, refer to Table 4 for the experimental scheme for finalizing the best ratio. In order to verify the experimental results, we have chosen $3 \#$ proportioning from the above experimental results in Table 4 for sample making before sending the sample to the Quality Control Department for testing. The testing results are shown in Table 5 listed below.

Tab.4 Experimental Scheme on Decorative Mortar

\begin{tabular}{|c|c|c|c|c|c|c|c|c|c|c|}
\hline & $1 \#$ & $2 \#$ & $3 \#$ & $4 \#$ & $5 \#$ & $6 \#$ & $7 \#$ & $8 \#$ & $9 \#$ & $10 \#$ \\
\hline Cement /\% & 25 & 30 & 25 & 30 & 25 & 45 & 40 & 25 & 25 & 25 \\
\hline Silica sand $\%$ & 65 & 60 & 65 & 60 & 65 & 45 & 50 & 65 & 65 & 65 \\
\hline Mineral admixture /\% & 6.35 & 6.35 & 6.85 & 6.85 & 6.5 & 6.35 & 6.35 & 7.05 & 7.5 & 7.7 \\
\hline Rubber powder /\% & 3 & 3 & 2.5 & 2.5 & 3 & 2.5 & 3 & 2.5 & 2.5 & 3 \\
\hline Moisture repellent /\% & 0.3 & 0.3 & 0.3 & 0.3 & 0.3 & 0.3 & 0.3 & 0.3 & 0 & 0.3 \\
\hline Cellulose ether /\% & 0.2 & 0.2 & 0.2 & 0.2 & 0.2 & 0.2 & 0.2 & 0 & 0 & 0 \\
\hline Antimitotic agent /\% & 0.15 & 0.15 & 0.15 & 0.15 & 0 & 0.15 & 0.15 & 0.15 & 0 & 0 \\
\hline
\end{tabular}

Note: The mineral admixture belongs to the second grade fly ash, the rubber powder is the re-dispersible emulsion powder 5044N, the moisture repellent is calcium stearate, the cellulose ether is hydroxypropyl methyl cellulose (HPMC), and the antimitotic agent is the polypropylene fiber of $3-5 \mathrm{~mm}$ in length.

Tab.5 Experimental Results of Decorative Mortar

\begin{tabular}{|c|c|c|c|c|c|c|c|c|c|c|c|}
\hline \multicolumn{2}{|c|}{ Item } & $1 \#$ & 2\# & $3 \#$ & 4\# & $5 \#$ & $6 \#$ & 7\# & $8 \#$ & 9\# & $10 \#$ \\
\hline \multirow{2}{*}{\begin{tabular}{|c|} 
Tensile \\
bond \\
strength \\
(with \\
modified \\
glass wool
\end{tabular}} & $\begin{array}{l}\text { Original } \\
\text { strength }\end{array}$ & 45 & 42 & 45 & 43 & 42 & 42 & 41 & 43 & 42 & 43 \\
\hline & $\begin{array}{l}\text { Water } \\
\text { resistance }\end{array}$ & 42 & 41 & 43 & 41 & 41 & 39 & 40 & 41 & 40 & 42 \\
\hline $\begin{array}{c}\text { glass wool } \\
\text { board) } \\
/ \mathrm{kPa}\end{array}$ & $\begin{array}{l}\text { Resistance to } \\
\text { freezing and } \\
\text { thawing }\end{array}$ & 41 & 41 & 43 & 40 & 40 & 38 & 40 & 41 & 40 & 40 \\
\hline $\begin{array}{r}\text { Ratio of } \\
\text { st }\end{array}$ & $\begin{array}{l}\text { compressive } \\
\text { rength }\end{array}$ & 2.21 & 2.45 & 2.33 & 2.40 & 2.35 & 2.56 & 2.49 & 2.25 & 2.38 & 2.34 \\
\hline Operati & ional time/h & 2 & 2.4 & 2.2 & 2.7 & 2.9 & 3.0 & 3.0 & 2.8 & 3.2 & 2.8 \\
\hline
\end{tabular}

The following results can be seen from Table 4 and Table 5.

a. The ratio of compressive strength of decorative mortar increases with the amount of cement and decreases with the increase of polymer and the fiber reinforced material.

b. By comparing formula 1\#, 2\#, 6\# and 7\#, the cement-sand ratio undergoes such changes as 1:2.6, $1: 2,1: 1$ and $1: 1.25$. It can be seen that the ratio of compressive strength reaches the maximum when the cement-sand ratio is $1: 2.6$.

c. Through modification by polymer and fiber reinforced material, the decorative mortar shows higher tensile bond strength and greater impact resistance.

It can be seen from the above analysis that the one-component decorative mortar made of dispersible adhesive powder, cement mortar and its addition agents as well as the glass wool board 
exhibit favorable original strength, water resistance, resistance to freezing and thawing and bonding strength. Upon testing, all its performance indicators comply with the requirements of the JG144-2004 Technical Specification for External Thermal Insulation on Walls.

\section{Development of Adhesion Agent}

As the glass wool board will be exposed to the air for a long term, the tiny fibers on its surface layer is liable to fall and hurt the construction workers and thus will cause inconvenience to the construction. So it is necessary to carry out interface treatment on its surface before the glass wool board has been applied to the wall. The interface treating agent is mainly made of cement and fine aggregate which shall be mixed with such modified materials as polymer and additives and so on in an appropriate ratio, before applying the mixture to the six facets of the modified glass wool board. Such treatment can prevent the tiny fibers on the surface layer of the glass wool board from flying, enhance the water resistance of glass wool board, and prevent the modified board from absorbing water from the leveling blanket, which keeps the leveling blanket from having crack born of quick loss of water and helps raise the bonding strength between the leveling material and the surface of the modified glass wool board. In this way, the entire ETIS will be ensured of a high stability.

The application of the adhesion agent to cover the six facets of the glass wool board will raise the material's water resistance, isolate the glass wool board and the cement and thus improve the alkali resistance of glass wool board. The electronic microscope photos of ordinary glass fiber and of glass fiber applied with adhesion agent are shown in Fig.5, 6 and 7 listed below.
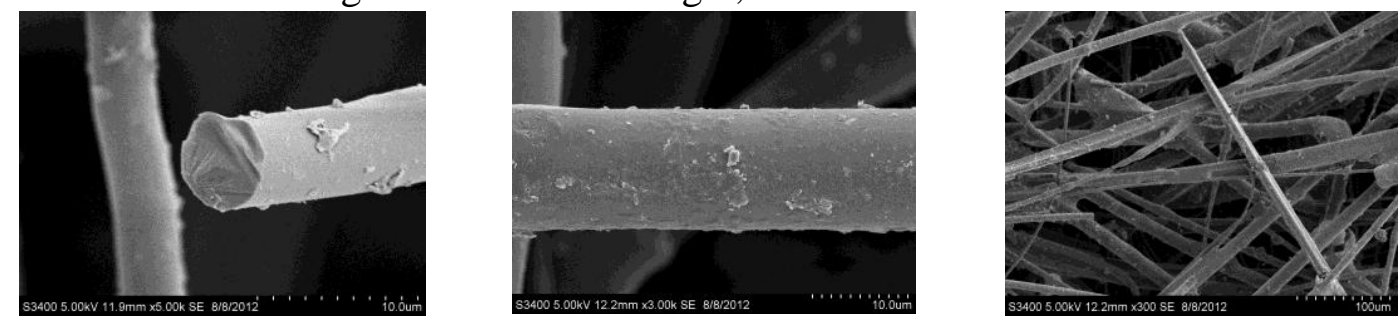

Fig.5 Electronic Microscope Photo of Ordinary Glass Wool


Fig.6 Electronic Microscope Photo of Glass Wool Soaked in Alkali Liquor


Fig.7 Electronic Microscope Photo of Alkali-Resisting Glass Wool Applied with Adhesion Agent

It can be seen from Fig. 6 that the ordinary glass fiber is seriously corroded after soaked in alkali liquor and its structure has basically been damaged. According to Fig.7, the glass fiber applied with 
adhesion agent, after soaked in alkali liquor, shows insignificant change and remarkable improvement in alkali resistance.

\section{Study of the Performance of Modified Glass Wool Board and the ETIS}

\section{Study of the Performance of Modified Glass Wool Board}

Study of Strength. Through the vertical pullout test and compression test on glass wool board, it is found that the perpendicular tensile strength and compression strength of glass wool board shows a gradual increase with the increase of its unit weight. The results of the pullout test and compression strength test on the glass wool board are shown in Table 6 listed below.

Tab.6 Results of Pullout Test and Compression Strength Test

\begin{tabular}{|c|c|c|c|c|}
\hline Sample No. & $\begin{array}{c}\text { Average thickness } \\
/ \mathrm{mm}\end{array}$ & $\begin{array}{c}\text { Average unit } \\
\text { weight } / \mathrm{kg} / \mathrm{m}^{3}\end{array}$ & $\begin{array}{c}\text { Perpendicular tensile } \\
\text { strength } / \mathrm{kPa}\end{array}$ & $\begin{array}{c}\text { Compression } \\
\text { strength }(10 \%) / \mathrm{kPa}\end{array}$ \\
\hline Bare board 1 & 25.5 & 62 & 1.9 & 6.9 \\
\hline Bare board 2 & 29 & 69.9 & 3.75 & 21.7 \\
\hline Bare board 3 & 35 & 80.2 & 4.5 & 40 \\
\hline Bare board 4 & 50 & 100.1 & 7.3 & 2.2 \\
\hline
\end{tabular}

Because the unit weight of glass wool board cannot keep increasing, the strength of glass wool board can be increased by sewing high-strength fibers along the longitudes and latitudes of the glass wool board. The experimental result shows that this method is feasible and the tensile strength perpendicular to the board has increased to over $15 \mathrm{kPa}$. The result is shown in Table 7.

Tab.7 Comparison of the Strength of Bare Board and Quilting Plate

\begin{tabular}{|c|c|c|c|c|}
\hline Sample No. & $\begin{array}{c}\text { Average } \\
\text { thickness } / \mathrm{mm}\end{array}$ & $\begin{array}{c}\text { Average density } \\
/ \mathrm{kg} / \mathrm{m}^{3}\end{array}$ & $\begin{array}{c}\text { Perpendicular tensile } \\
\text { strength } / \mathrm{kPa}\end{array}$ & $\begin{array}{c}\text { Compression } \\
\text { strength }(10 \%) / \mathrm{kPa}\end{array}$ \\
\hline Bare board & 50 & 100 & 7.3 & 40 \\
\hline Quilting plate & 50 & 113.4 & 15.6 & 40.2 \\
\hline
\end{tabular}

Study of Noninflammability. The biggest advantage for the glass wool board to be applied to the external thermal insulation for buildings is its noninflammability. Its combustion performance can come up to grade A1. But this has a close connection with the glue consumption during the production of glass wool board. If the glue consumption is too large, the noninflammability will decrease. If the glue consumption is too small, the strength of the glass wool board cannot come up to the standard. After repeated experiments that are based on the precondition that the strength of the glass wool board is up to the standard, the glue consumption shall be $9 \%$.

Research of Flammability is as follow. The noninflammability of glass wool board is related to the glue consumption during production. When the glue consumption reaches $9 \%$, the grade A indicator as stipulated in GB8624-2012 Classification of Building Material and Flammability of Products is complied with, i.e. $\Delta \mathrm{T} \leq 30^{\circ} \mathrm{C}, \Delta \mathrm{m} \leq 50 \%$, and $\mathrm{t}_{\mathrm{f}}=0$. 


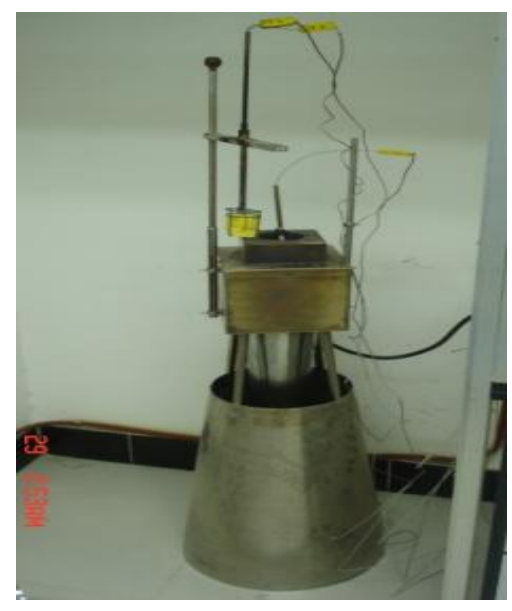

Fig.8 Non-burning Furnace

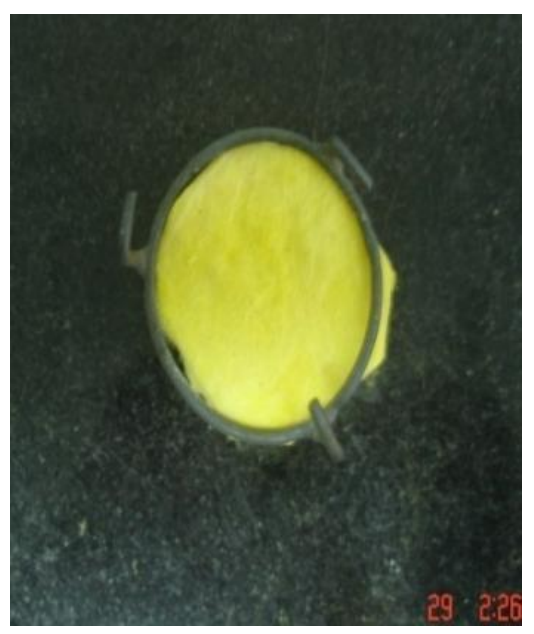

Fig.9 Before the Sample is Burnt

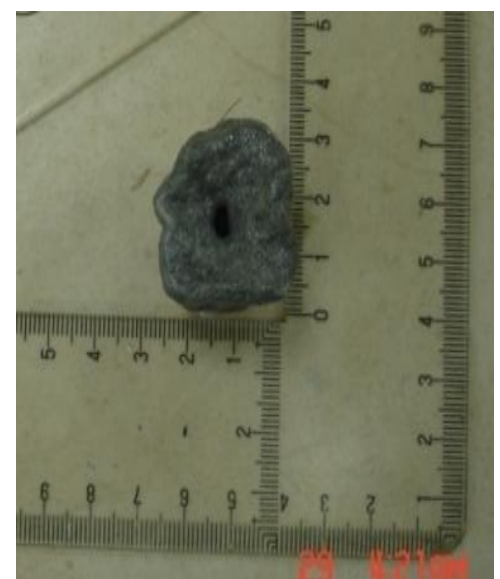

Fig.10 After the Sample is Burnt

The experimental results on noninflammability are: $\Delta \mathrm{T}=15.0^{\circ} \mathrm{C}, \Delta \mathrm{m}=12.3 \%$ and $\mathrm{t}_{\mathrm{f}}=0$, which comply with the standard.

\section{Study on the ETIS Performance}

Weatherability of System. The study is carried out pursuant to the JGJ144-2014 Technical Specification for External Thermal Insulation on Walls and the local standard of Beijing -Technical Specification for External Thermal Insulation on Outer-Walls DB11/T1117-2014. When the 
maintenance for the system model has expired, it is classified into three parts from the left to right (Fig.11).
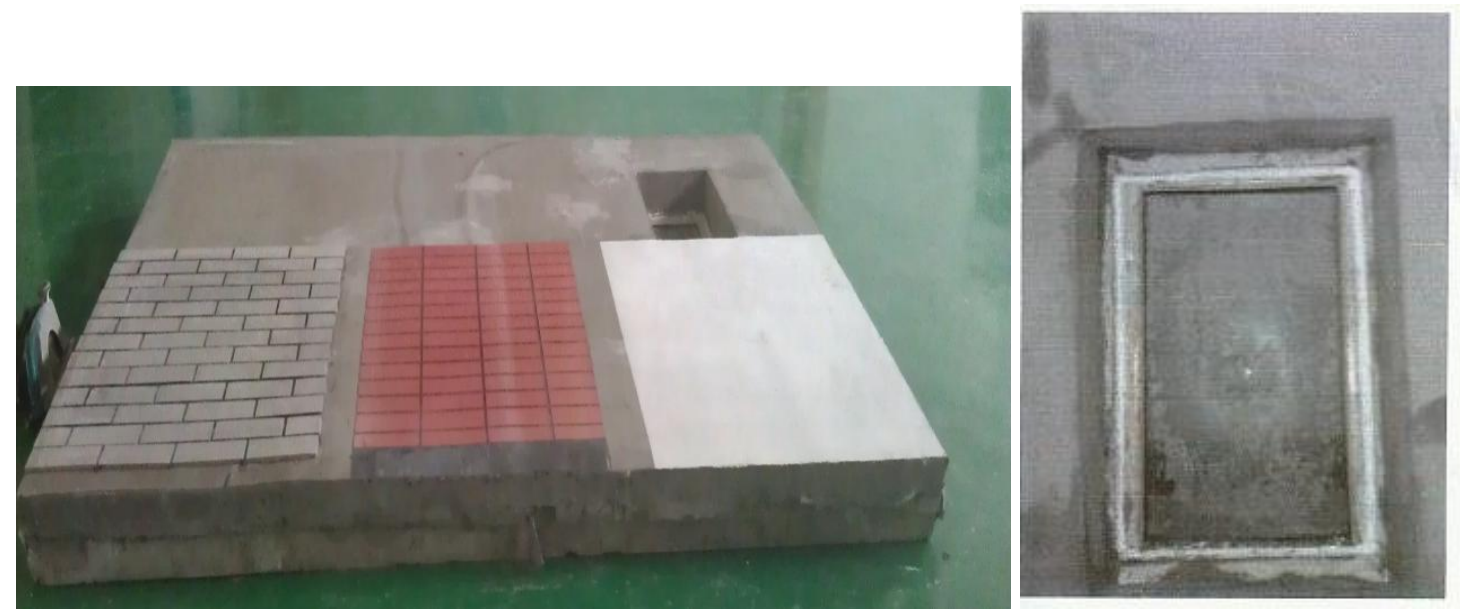

Fig.11 Status of System and Window after the Weather Resistance Test

The tile facing, decorative mortar facing and the coating facing are shown from left to right respectively. After they have undergone 80 hot/ rain cycles, placed for 48 hours and 5 hot/cold cycles, observe if there are cracks, blisters or peeling on their system surfaces. The experimental results are shown in Table 8.

Tab.8 Experimental Results on the Weather Resistance of Modified Glass Wool Board-based ETIS

\begin{tabular}{|c|c|c|c|c|c|}
\hline No. & \multicolumn{2}{|l|}{ Item of test } & Requirements & Testing result & $\begin{array}{l}\text { Conclusio } \\
n\end{array}$ \\
\hline \multirow{4}{*}{1} & \multirow{4}{*}{$\begin{array}{lr}\text { High } & \text { temp. } \\
\text {-water } & \text { spray } \\
\text { cycle } & (80 \\
\text { times }) & \end{array}$} & Window & ------ & $\begin{array}{l}\text { The window is not } \\
\text { damaged and free from } \\
\text { connected crack. }\end{array}$ & ------ \\
\hline & & $\begin{array}{l}\text { External tile } \\
\text { facing }\end{array}$ & $\begin{array}{l}\text { The surface shows no } \\
\text { crack or peeling. }\end{array}$ & $\begin{array}{l}\text { The surface shows no } \\
\text { crack or peeling. }\end{array}$ & Qualified \\
\hline & & $\begin{array}{l}\text { Colored } \\
\text { mortar facing }\end{array}$ & $\begin{array}{l}\text { The surface shows no } \\
\text { crack, pulverization or } \\
\text { peeling. }\end{array}$ & $\begin{array}{l}\text { The surface shows no } \\
\text { crack, pulverization or } \\
\text { peeling. }\end{array}$ & Qualified \\
\hline & & $\begin{array}{l}\text { Whitewash } \\
\text { facing }\end{array}$ & $\begin{array}{l}\text { The surface shows no } \\
\text { crack, pulverization or } \\
\text { peeling. }\end{array}$ & $\begin{array}{l}\text { The surface shows no } \\
\text { crack, pulverization or } \\
\text { peeling. }\end{array}$ & Qualified \\
\hline \multirow{4}{*}{2} & \multirow{4}{*}{$\begin{array}{l}\text { Heating and } \\
\text { freezing } \\
\text { cycle } \\
\text { times })\end{array}$} & Window & ------ & $\begin{array}{l}\text { The window is not } \\
\text { damaged and free from } \\
\text { connected crack. }\end{array}$ & ------ \\
\hline & & $\begin{array}{l}\text { External tile } \\
\text { facing }\end{array}$ & $\begin{array}{l}\text { The surface shows no } \\
\text { crack or peeling. }\end{array}$ & $\begin{array}{l}\text { The surface shows no } \\
\text { crack or peeling. }\end{array}$ & Qualified \\
\hline & & $\begin{array}{l}\text { Colored } \\
\text { mortar facing }\end{array}$ & $\begin{array}{l}\text { The surface shows no } \\
\text { crack, pulverization or } \\
\text { peeling. }\end{array}$ & $\begin{array}{l}\text { The surface shows no } \\
\text { crack, pulverization or } \\
\text { peeling. }\end{array}$ & Qualified \\
\hline & & $\begin{array}{l}\text { Whitewash } \\
\text { facing }\end{array}$ & $\begin{array}{l}\text { The surface shows no } \\
\text { crack, pulverization or } \\
\text { peeling. }\end{array}$ & $\begin{array}{l}\text { The surface shows no } \\
\text { crack, pulverization or } \\
\text { peeling. }\end{array}$ & Qualified \\
\hline 3 & \multicolumn{2}{|c|}{$\begin{array}{l}\text { The tensile bond strength } \\
\text { between the protective facing } \\
\text { and the modified glass wool } \\
\text { board, } \mathrm{kPa}\end{array}$} & $\geq 15$ & 26 & Qualified \\
\hline
\end{tabular}


Wind Pressure Test. The wind pressure test is carried out pursuant to the JGJ144-2014 Technical Specification for External Thermal Insulation on Walls and the local standard of Beijing -Technical Specification for External Thermal Insulation on Outer-Walls DB11/T1117-2014. Circular pressurization shall be carried out when the maximum wind load $\mathrm{W}$ designed by the engineering project reduces by $2 \mathrm{kPa}$. One cycle shall be carried out when $1 \mathrm{kPa}$ is increased, until damage. The testing results are shown in Table 9.

Refer to Fig. 12 for photos on the comparison before and after the wind pressure test.
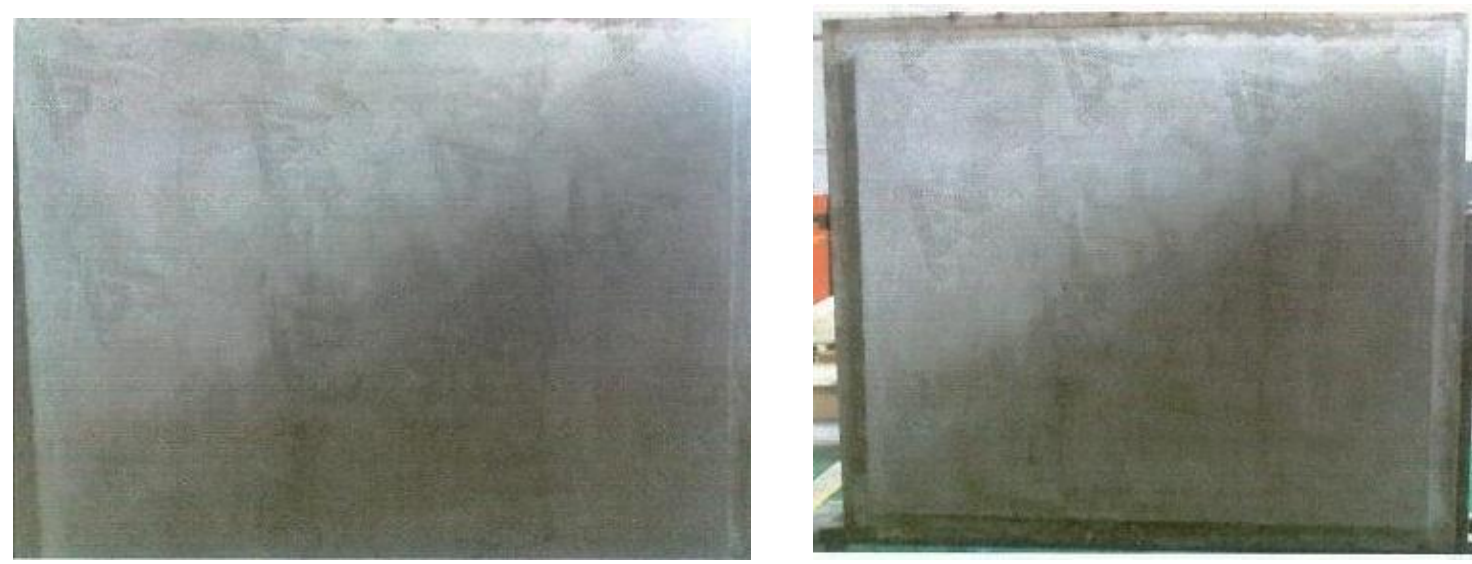

Fig.12 Photos on Comparison before and after the Wind Pressure Test

Tab.9 Results on the Wind Pressure Test of Modified Glass Wool Board-based ETIS

\begin{tabular}{|c|c|c|c|}
\hline $\begin{array}{c}\text { Item of test / } \\
\text { Surface features of results }\end{array}$ & $\begin{array}{l}\text { Test of wind load } \\
10 \mathrm{kPa}\end{array}$ & $\begin{array}{l}\text { Test of wind load } \\
\qquad 11 \mathrm{kPa}\end{array}$ & $\begin{array}{c}\text { Test of wind load } \\
12 \mathrm{kPa}\end{array}$ \\
\hline No fracture on the insulation board & Qualified & Qualified & Qualified \\
\hline $\begin{array}{l}\text { No layering in the insulation board } \\
\text { or between the insulation board and } \\
\text { the protective coating }\end{array}$ & Qualified & Qualified & Qualified \\
\hline $\begin{array}{l}\text { No disconnection on the protective } \\
\text { coating }\end{array}$ & Qualified & Qualified & Qualified \\
\hline $\begin{array}{l}\text { No separation between the } \\
\text { insulation board and the base layer }\end{array}$ & Qualified & Qualified & Qualified \\
\hline Anti-wind pressure value & \multicolumn{3}{|c|}{$\begin{array}{l}\text { Anti-wind pressure value } \\
\times \mathrm{Ca} \times \mathrm{Cs} / \mathrm{m}=12 \times 1.0 \times 1.0 / 1.5=8 \mathrm{kPa}\end{array}$} \\
\hline
\end{tabular}

Water Absorption Test. This test is carried out pursuant to the JGJ144-2014 Technical Specification for External Thermal Insulation on Walls and the local standard of Beijing -Technical Specification for External Thermal Insulation on Outer-Walls DB11/T1117-2014. Weigh the samples by balance and then stably put the facet of the sample applied with decorative mortar into the water of room temperature. The immersion depth shall equal the thickness of the layer applied with mortar. The surface shall be thoroughly wet when put into the water. After the sample has been dipped into the water for 24 hours, take it out and quickly wipe off the water on the surface of sample by towel. Test its weight after the above-mentioned 24 hours and calculate its water absorbing capacity. The experimental results are shown in Table 10. 
Tab.10 Experimental Results on the Water Absorbing Capacity of Glass Wool Board-based ETIS

\begin{tabular}{|c|c|c|c|}
\hline \multicolumn{2}{|c|}{ Item of test } & Standard & Test result \\
\hline \multirow{2}{*}{$\begin{array}{c}\text { Water absorbing } \\
\text { capacity, } \mathrm{g} / \mathrm{m}^{2}\end{array}$} & Decorated layer & 500 & 257 \\
\cline { 2 - 4 } & $\begin{array}{c}\text { Layer without } \\
\text { decoration }\end{array}$ & 500 & 450 \\
\hline
\end{tabular}

Shock Strength. This test is carried out pursuant to appendix A.5 to the JGJ144-2014 Technical Specification for External Thermal Insulation on Walls and based on the vertical free fall impact method. Put the protective layer of the sample flatwise onto a smooth rigid plate upward and closely connect the sample with the plate. Impact the sample with a $1000 \mathrm{~g}$ steel ball from a height of $1.02 \mathrm{~m}$ by free fall. The impact points shall keep a distance of at least $100 \mathrm{~mm}$ with the sample edge and the spacing between the impact points shall be no less than $100 \mathrm{~mm}$. The crack of the impact points and of their surrounding areas shall be deemed as being damaged. The experimental results are shown in Table 11.

Tab.11 Experimental Result on the Shock Strength of Glass Wool Board-based ETIS

\begin{tabular}{|c|c|c|c|}
\hline Item of test & Standard & Test result & Conclusion \\
\hline Shock strength & $\begin{array}{c}\text { 10J impact for 10 times; the } \\
\text { times of crack shall be no } \\
\text { more than 4. }\end{array}$ & $\begin{array}{c}\text { 10J impact for 10 } \\
\text { times; times of crack: } \\
\text { two }\end{array}$ & Qualified \\
\hline
\end{tabular}

Test on Resistance to Freezing and Thawing. This test is carried out pursuant to the JGJ144-2014 Technical Specification for External Thermal Insulation on Walls and the local standard of Beijing -Technical Specification for External Thermal Insulation on Outer-Walls DB11/T1117-2014, that is, cycle of freezing and thawing of 30 times, 24 hours each time. Soak the sample in the tap water of $(20 \pm 2)^{\circ} \mathrm{C}$ for 8 hours. When the sample is immersed in the water, make sure the rendering coat or the covering layer faces the water. Immerse the rendering coat into the water and remove the bubbles on the sample surface. After that, freeze the sample in the $(-20 \pm 2)^{\circ} \mathrm{C}$ refrigerator for 16 hours. Observe if there are crack, hollowing, falling, etc. on the sample after every three cycles and make records. After the test, adjust the status to $7 \mathrm{~d}$, and then test the tensile adhesive strength of the sample. The experimental results are shown in the following table.

Tab.12 Experimental Result on Resistance to Freezing and Thawing of Glass Wool Board-based ETIS

\begin{tabular}{|c|c|c|c|}
\hline \multicolumn{2}{|c|}{ Item of test } & Standard & Test result \\
\hline $\begin{array}{c}\text { Resistance to } \\
\text { freezing and } \\
\text { thawing }\end{array}$ & Appearance & $\begin{array}{c}\text { No crack, hollowing, } \\
\text { bubble or peeling on the } \\
\text { surface. }\end{array}$ & $\begin{array}{c}\text { No crack, hollowing, } \\
\text { bubble or peeling on the } \\
\text { surface. }\end{array}$ \\
\cline { 2 - 4 } & Bonding strength & $\begin{array}{c}\geq 15 \mathrm{kPa}, \text { the broken part } \\
\text { is in the insulation layer }\end{array}$ & $\begin{array}{c}\geq 21 \mathrm{kPa}, \text { the broken part } \\
\text { is in the insulation layer }\end{array}$ \\
\hline
\end{tabular}

Test on Wet Density of Steam. This test is carried out pursuant to the JGJ144-2014 Technical Specification for External Thermal Insulation on Walls, and the experimental result is shown in Table 13. 
Tab.13 Experimental Result on the Wet Density of Steam of the Glass Wool Board-based ETIS

\begin{tabular}{|c|c|c|}
\hline Item of test & Standard & Test result \\
\hline Wet density of steam $\mathrm{g} /\left(\mathrm{m}^{2} \cdot \mathrm{h}\right)$ & $\geq 0.85$ & 4.45 \\
\hline
\end{tabular}

Impermeability Test. This test is carried out pursuant to the JGJ144-2014 Technical Specification for External Thermal Insulation on Walls, and the experimental result is that the inner side of the sample's covering layer is free of water penetration.

To summarize, all the indicators of the modified glass wool board-based ETIS have come up to the standards of the JGJ144-2014 Technical Specification for External Thermal Insulation on Walls and the Technical Specification for External Thermal Insulation on Outer-Walls DB11/T1117-2014 of Beijing.

\section{Application and Promotion}

From 2011 to 2012, the modified glass wool board-based ETIS had been applied in the energy-saving renovation project in Xicheng District, Beijing, which involves a building area of more than 600,000 sq. meters and shows desirable effect.

The related application projects are shown in Picture 10: in the middle of the construction of Lingjing Lane Housing Estate (pictures above) and after the construction of Wanming Park Housing Estate (pictures below).

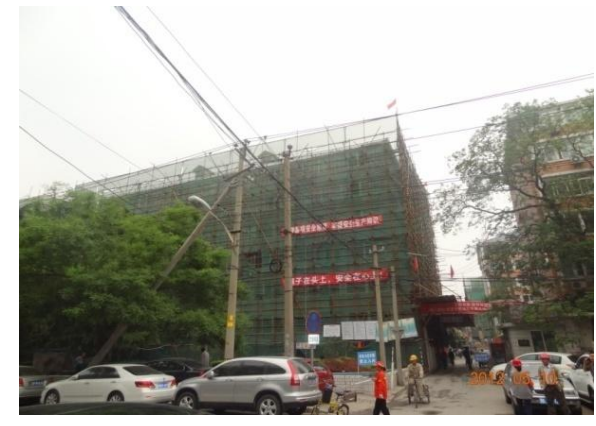

a. Before Construction

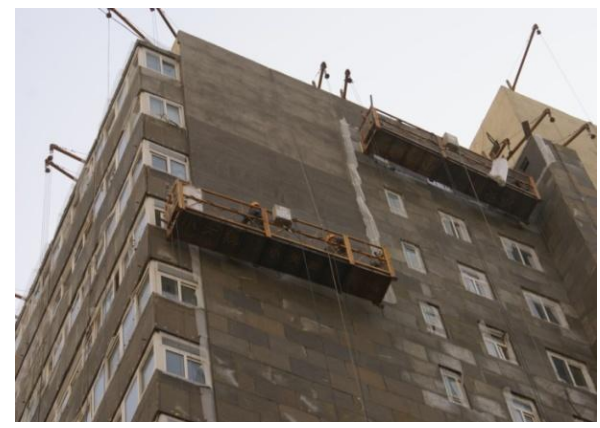

c. During Construction

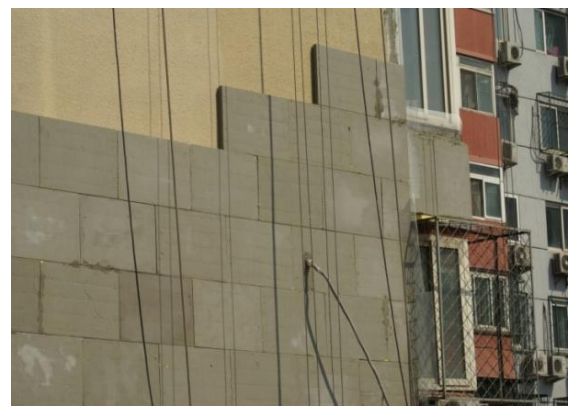

b. During Construction

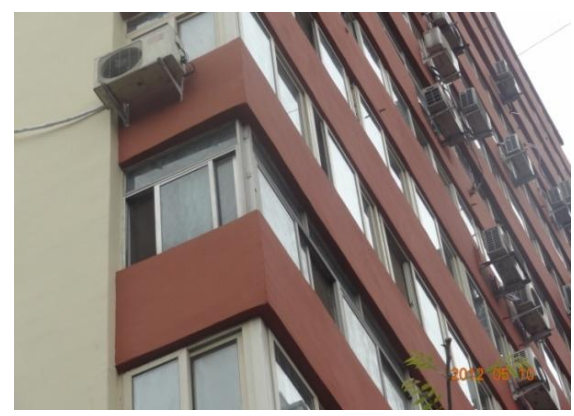

d. After Construction

\section{Summary}

This paper revolves around the development of the modified glass wool board-based ETIS and the experimental study on the modified glass wool board-based ETIS and the performance of its main materials. It also gives a detailed analysis on the influence of various additives on the mechanical properties of polymer mortar, conducts contrastive analysis on the vertical pulling strength and compression strength of the bare board and the longitude-and-latitude sewn board and conducts a series of experimental studies on the weather resistance, wind pressure resistance, water absorption, 
shock strength, freeze-thaw resistance, wet density of steam, and water impermeability of the ETIS before drawing the following conclusions.

1. Find out the most appropriate ratio between bonding mortar and decorative mortar; the best result shows when the cement-sand ratio is $1: 2.5$ and 1:2.6 respectively.

2. The adhesion agent for glass wool board has been developed, which effectively raises the waterproofness and alkali resistance of glass wool board.

3. Compared with bare board, the longitude-and-latitude sewn glass wool board shows insignificant change in compression strength and marked increase in perpendicular tensile strength, i.e. increased from $7.3 \mathrm{kPa}$ to $15.6 \mathrm{kPa}$.

4. By conducting the non-combustibility test and whilst ensuring the strength of the glass wool board is up to the requirement, it is found out that the glue consumption shall be $9 \%$.

5. The results from multiple experimental studies on the modified glass wool board-based ETIS indicate that both the glass board and the ETIS can come up to the JGJ144-2014 Technical Specification for External Thermal Insulation on Walls and the local standard of Beijing -Technical Specification for External Thermal Insulation on Outer-Walls DB11/T1117-2014, and the product shows desirable effect in the Lingjing Lane Housing Estate and Wanming Park Housing Estate.

\section{References}

[1] AN Changyou, HUANG Zhenli, LI Guangqi, etc., Current Situation and Discussion on Fire Protection Technology of Exterior Insulation [J]. Building Science, 2008, 24(2): 1-9.

[2] AN Changyou, CHEN Danlin, HUANG Zhenli, etc., Research on Technology of the Fire-Resistant External Thermal Insulation System of Abscission-Layer Buildings [J]. Building Science, 2008, 24(2): 93-106.

[3] HUO Yi, Analysis and Comparison on Performance of EPS and XPS Board, Construction Technology, 2011, (9): 68-70.

[4] WU Di, Research on the Flammability of Commonly-Used Organic Insulation Materials [J]. New Building Materials, 2014, (4): 18-21.

[5] XU Zhizhong, LI Tiedong, Thinking on the Prospect of Organic Insulation Materials for Buildings [J]. New Building Materials, 2011, (7): 27-30. 